DOI https://doi.org/10.36059/978-966-397-190-2/17-31

\title{
STATE AND COMMUNICATIONS IN THE WORKS OF THE THINKERS OF THE PAST
}

\section{Denis Kislov}

\section{INTRODUCTION}

The contemporary scientific discourse on the definition of the essence and nature of communications and communicativeness in the political, state, and economic fields is becoming more and more critical and fundamental. This situation demands a more thorough insight into the historical concept interpretation evolution based on an understanding of the interrelationships of management and communications at various historical periods, which is reflected in the works of the most prominent thinkers of the past. At the same time, this comparative analysis should take into account a contemporary view of the essence, meaning, and nature of these phenomena within the context of their relation to political and social processes. The initial documented theoretical descriptions of these processes encompass the period of state formation in the age of antiquity and Ancient China. The ideas of philosophers of that civilization period are still relevant and demanded in contemporary theoretical developments. The key motive of this publication is to demonstrate this dependence and the relevant recourse to the works of the prominent thinkers of the past for rethinking the contemporary concepts from a standpoint of universal values. The purpose of this chapter is to analyze the evolution of the views of ancient thinkers' communications and management phenomena in terms of the contemporary understanding of these terms. The methodology used in this study employs a system approach and a comparative historical analysis. In the history of philosophical and political thought, there were certain sufficiently sound ideas of interrelationships between the authorities and the population, which may serve as a basis for developing new concepts or revaluing the existing ones. The scientific novelty of this publication consists in the detailed and systemic rethinking of the thinkers' views at the earlier stages of statehood from the perspective of the contemporary theory of civilization management and communication relationships for the $21^{\text {st }}$ century. A heated discourse within the national research and management community is presently held on the concept of the New Public Management that started in the West back in the 1980s - 1990s. Ideas proposed to improve the efficiency of management decisions rely on a proposal to upgrade the interaction of communications systems of stateowned, private, and nongovernmental institutions. And it points again to the 
relevance of focusing on the essence of the initial theoretical statements free from any experience of others and from ideologies.

An analysis of theoretical works dedicated to the development of state and political information and communications systems taking into account past historical experience shows that the focus of a number of national and foreign authors on historical analogies and appeals is growing. Within the context of this chapter theme and from the political and information perspective the following Ukrainian researchers should be emphasized: V. Bebik, O. Zernetska, V. Rizun, A. Kholod, and also researchers focusing on communications in connection with the state administration issues such as V. Bakumenko, A. Bukhtaty, N. Dragomyretska, V. Ivanov, L. Klymanska, V. Kniazev, E. Romanenko, G. Pocheptsov. Foreign specialists working in this field from the historical perspective relevant to the antiquity era include G. Gersimova, T. Kessidis, K. Kule, U. Eco, and several other authors.

\section{Understanding communications in the political processes of the state system of antiquity}

In the period when philosophical views on political processes of antique slave owning states (late $7^{\text {th }}$ century - early $6^{\text {th }}$ century B.C.) were formed at the time of the Seven Wise Men of Ancient Greece, the first statements on the role of information and communications (as translated into the contemporary language) was made by one of them - Bias of Priene.

In the ideal state concept described in the works of Plato (427-347 B.C.) such as "State", "Critias", "Polity", and "Laws", communications management was considered in the context of "kingdom of art" based on the knowledge and talent of communications among (free) people and communications between the authorities and people (with free citizens and warriors). The political communications art according to Plato is an ability to weave a political fabric for the electoral unity of brave, prudent, and friendly like-minded people. Plato believed that the public and private life of citizens, the level of information and communications available to them should be regulated only through a thorough legislative system. He proposed a balanced approach to regulation of communicative relationships in a system of democratic state administration, emphasizing that art primarily relies on the "knowledge of what is beautiful and useful, artistic knowledge of justice in the state"1.

According to Aristotle (384-322 B.C.), the state is the highest form of communications, but only for free citizens who may participate in legislative,

${ }^{1}$ Plato. (1999) Zakony [Laws] / translated from Ancient Greek by A. Losev, V. Asmus, A. Godi. Moscow. Mysl, p. 618. 
judicial, and military activities. Aristotle viewed only "polity" as an ideal form of the state in the form of an original unity of democracy and oligarchy (in antique terms). He believed that a middle class is to be artificially formed through the proportionate and electoral recruitment of poor class representatives for public posts in order to ensure the optimal administration of this form of statehood. Interrelations between free citizens (slave owners) and slaves, craftsmen and the other categories of the population, just as all the types of family relations, were thought by Aristotle to be beyond the political communications zone. He was the first to introduce the classification of what we call communications. Aristotle classified them into regulated, substatutory, formal, informal, and unregulated communications. His "to each their own" maxim referred to the delimitation of the sphere of influence and communications corresponding to it. It means that in the state everyone has to do what they have to and not to interfere with relationships of other categories of the population. In other words, all types of political communications are strictly divided and intertype ones are extremely limited. Aristotle believed that this would ensure fair reconciliation of the state's objectives and the relevant balanced "reconciliation of laws to achieve the general welfare of citizens"2.

Until the mid-20 ${ }^{\text {th }}$ century, the structure of communications was considered as proposed by Aristotle according to the speech formula divided by him into three components: "orator", "subject matter he talks about", and "person he addresses"3. The content of communications was specified according to G. Lasswell's formula obtained based on long scientific research into the radio as the media and its impact on the American society in 1937-1948. Unlike Aristotle's three-dimensional formula, it consisted of five elements of the communications process ${ }^{4}$.

In the years to come and until our time, this has pushed to the permanent increase in the number of elements of communications formulas. In the second half of the $20^{\text {th }}$ century - the early $21^{\text {st }}$ century, fuller records of the content of messages were attributed to authors of new communications formulas. However, Aristotle defined the proportion between the content and scope of concepts communicated from the orator (communicator) and a person. According to Aristotle's logic, a higher scope of concepts in communication decreases their content and vice versa, but it was not reflected

2 Aristotle (2000) Polityka [Polity] / translated from Ancient Greek and foreword by O. Kysliuk, Kyiv, Osnovy, p. 88.

3 Aristotle. Retorica [Rhetoric] (2000) Poetry / translated from Ancient Greek by O. Tsybenko. Moscow, Labirint, p. 197.

${ }^{4}$ Kislov D. (2019) Establishment of scientific research in communication studies in the 1920s - 1930s. History of science and technology. Vol. 9, issue 1 (14). P. 105. 
in his formula. The freedom of communication and the freedom of information distribution were directly linked by Aristotle to the process of emergence and development of city-states, statehood, and democracy and for him this was an inseparable attribute of their existence just as man's ability to speak.

The need to influence the enemy's human communication and the military forces, other facilities arose at the early stages of statehood establishment. Such communicative measures were implemented by way of disseminating rumors, myths, information on the invincibility and power of the conquerors' troops. And information on such measures supposed to be implemented long before they were really implemented in the specific area have been known since the ancient times from the Bibles, annals, and chronicles, from antique and oriental myths, folklore of different countries and nations.

Dissemination of information on invincibility was successfully used by Aristotle's pupil: Alexander the Great. This was his strategic technique and permanent component of brilliant victories and fast conquests of vast territories. Information on Alexander the Great's victories was disseminated across the territories of potential enemies to spread fear and panic among the adversary's population and troops. This worked until his troops met an enemy with a fundamentally different code of information fears and prejudices. Moreover, Alexander the Great used a method that was later called "connection": inclusion of a new item in the old mythology.

Before the final conquest of Greek city-states (poleis), Alexander the Great imposed a condition, according to which all their citizens had to recognize him as a son of Zeus, although the ancient world back then was well aware that he was the son of King Philip II. Having uneasily admitted this allegation, residents of ancient Greek city-states made their first important step toward a loss of democracy, which later had a significant effect on the consciousness of all the surrounding countries and nations of the antique world ${ }^{5}$. Over thousands of years, the connection method was tested and is still successfully used by political strategists when the mythologeme of one system, formation needs to be replaced with another one (the positive one with the negative one and vice versa). This method became an infallible tool of an information war particularly in case of discrediting the current or past personalities not at the best time of social and economic transformations.

In the ancient world, similar substitutions happened not just to personalities, but to certain concepts as well, representing an information war technique. For example, the initial term "demagogue" meant a national chief,

${ }^{5}$ Pocheptsov G. G. (2002) Psikhologicheskie vojny [Psychological wars]. Moscow. Reflbook, Kyiv. Vakler, p. 225. 
a democratic politician within the state system as viewed in the antique world, although a people was defined as all the free slave owning citizens of a citystate and included only men. Later, in the period of an external struggle against the democratic system, this term was ironically and scornfully applied to individuals defending the previous principles. As a result, the term "demagogue" was transformed and began to mean a public figure deceiving people by unfeasible promises, false mottos, flattery, manipulation or misrepresentation of facts. In other words, demagogues and false informers (misinformers) became the leading fighters of information wars. As a method of consciously constructed false statements and calls hiding selfish and egoistic objectives, demagogy has been used for thousands of years and will be used as long as an information and political struggle exists.

In his work "History of Rome", Theodor Mommsen provided a detailed and bright description of the life in this antique state's capital. Liars and boasters could be easily found and used for disseminating any rumors in Rome. T. Mommsen wrote that there were enough chatterboxes and rascals capable of discrediting others and ready to do everything they were ordered to: tell lies, say bad things about something good and vice versa, act as false witnesses, false prophets, and disseminate any disinformation ${ }^{6}$. And such lumpen people were actively used in Ancient Rome as elements of oral communication in the information component of political and military struggle. According to Cornelius Tacitus, rumors and dirt were actively used behind the screen of "vox populi", i.e. voice of the people, against competitors, enemies and opponents of politicians and legionaries?

T. Mommsen's insight into the everyday life, behavior, and destinies of Roman residents made it possible to develop models of ancient analogies of ordered information and disinformation dissemination systems through oral communications. And such models based on the moral and psychological condition of society in the Roman State are quite an efficient tool in comparative historical analogies. T. Mommsen clearly emphasized the role of spectacular communications with elements of murders and violence (Roman holidays, including during burials, hunting and killing wild animals in the presence of large crowds of people, including children) in the formation of the society's customs and psychological condition of that time. Contemporary cinema and television strictly follow this path of Roman society, which leads to deterioration and decay, but not spontaneously as in was in the ancient

\footnotetext{
${ }^{6}$ Mommsen T. (1997) Istoriya Rima : $v 4$ tomah [History of Rome: in 4 volumes]. Rostov on Don. Fenix, v. 2: Unification of Italy before the conquest of Carthage and Greek states (book III continuation). Revolution (book IV). P. 194.

${ }^{7}$ Tacitus C. (1969) Istoriya. Istoriki Rima [History. History of Rome]. Moscow. Nauka, p. 348.
} 
world, but in a fully aware and purposeful way as an element of information wars.

T. Mommsen clearly demonstrated that the "revolution of vicious practices" in Rome was followed by economic crises, revolutions, ruin, and enslavement by barbarians - arriving conquerors. The vicious population was unable to resist aggressive and cruel conquerors. He wrote that if a person receives no satisfaction from labor, works only to enjoy life, he/she does not become a criminal thanks to a happy occasion. The destiny generously offered all the benefits associated with power and wealth to Romans, but the can of worms actually turned out to be a gift with dubious merits ${ }^{8}$. This thesis written about 165 years ago (in 1854-1856) is still relevant for the contemporary Euro-Atlantic civilization as well.

Artificially formed misinforming rumors were disseminated in Ancient Rome by specially trained people. They were an efficient tool for discrediting certain officials and changing the mood of the crowd, which stated requirements and calls wanted by their intriguing organizers.

However, this threat still affects many present-day politicians as well. The same motto (voice of the people) is currently used by some political analysts along with a group of tame media professionals to persuade that a show demagogy is a real popular opinion by relying on audiences prefabricated and adapted to their objectives. However, this is not done in the marketplaces of Ancient Rome, but on the scenes of reputed contemporary television channels.

Gaius Julius Caesar (100-44 B.C.) used the method of spectacular entertainment communications for the purposes of information support of his power and message as well. He initiated various massive spectacles, holidays, jubilees, and other similar events. This was the beginning of targeted image and marketing (as understood today) actions and measures permitting to widely disseminate the information on the greatness and importance of J. Caesar, on his perpetuation not just among his contemporaries, but in the history of humankind in general. According to Plutarch in his Comparative Life Descriptions, J. Caesar actively used bribery, rumors, and also other methods for various purposes and in various situations, obtaining finally "the greatest benefits at a low price" (Plutarch, 2008). Manifestations, ceremonies, magnificent spectacles were sufficiently bright, colorful, and large-scale events at that time. They all were prototypes of methods and technology of psychological effects on the consciousness of people. Mechanisms and tools of such effects have not, in principle, changed since that time.

\footnotetext{
${ }^{8}$ Mommsen T. (1997) Istoriya Rima : v 4 tomah [History of Rome: in 4 volumes]. Rostov on Don. Fenix, v. 2: Unification of Italy before the conquest of Carthage and Greek states (book III continuation). Revolution (book IV). P. 197.
} 
In the ancient world, prophecies spread by oracles, priests, and other sources reputed at that time were widely used in information conflicts to efficiently manage the collective consciousness. This method has never been disdained. Prophecies of the end of the world or other apocalypses circulated from time to time today become practically the main theme of all the media outlets causing mass psychoses that can divert the population from more relevant and practical themes and objectives and justify unpopular measures. Therefore, the principles of impacting the collective consciousness developed in the antique world have never changed or become outdated. These methods are still efficient in contemporary information wars, but they have new communications and technological forms.

The political and theoretical thought of Ancient Rome was most vividly described in the works of Marcus Tullius Cicero (106-43 B.C.). Relying on Polybius's opinions about the Roman society as a synthesis of the monarchy, aristocracy, and democracy, he followed Plato's theoretical instructions. Cicero established the general theoretical and legal basis for international political communications and theory of wars described in his works such as "On Laws", "On the State" known as the Dialogues on the state9. He defended an aristocratic, particularly careful and balanced attitude to communications in management. In particular, Cicero introduced the concept of just and unjust wars, which is still used in the theories of wars by all ideologies. The basics of the doctrinal definition of information wars appeared more than 2,000 years ago, but their essence and link to the state policies were rethought only in the $20^{\text {th }}$ century when definitions associated with information technology were introduced in the legislative practices of many states.

Therefore, new methods and technology of public management and their further improvement will not be developed in a sustainable and full manner without rethinking the heritage of the antique understanding of the development of human communications in the political processes of the state.

\section{Management and communications issues as priority of Ancient Chinese thinkers}

An analysis of the historical period of development of theoretical management and communication ideas and principles in the context of the formation of the key schools of philosophy in Ancient China points shows the careful attention of the representatives of Confucianism, Laoism, and Moism in the $6^{\text {th }}-3^{\text {rd }}$ centuries B.C. to the issues of communications between the

\footnotetext{
${ }^{9}$ Macklin I. and Macmillan A. (2005) Korotkij oksfords 'kij poli'tichnij slovnik [Brief Oxford political dictionary] / edited by, translated from English by V. Sydorov and others, Kyiv, Osnovy, p. 746.
} 
authorities and the population. The typical feature of the era called "Struggle of Kingdoms" was a consistent aspiration to establish a united centralized state and relevant attempts to bring together the theory and practice in the state administration reformation by recruiting the representatives of thenfamous schools of philosophy, being just established, to the administrative bodies.

Methods of influencing the population, enemy environment and armies in the period of statehood development in the Middle East, Central and SouthEast Asia are described in the legends and history of oriental nations. Rumors of the super power of any conquerors were always disseminated in advance in the territories to be aggressed.

The history of political thought knows the theoretical concepts of Chinese philosophers concerning the nature of power, state development, and the role of governors, the people, officials, and relationships between them. Certain communication interdependence of the authorities and a man of the people is a specific feature of both the myth creation and ancient Chinese ideology and philosophy ${ }^{10}$.

The clearest definitions of communications in the context of understanding the society and state management issues of that time were given by the prominent thinkers of Ancient China: founders of the first schools of philosophy in the $6^{\text {th }}-2^{\text {nd }}$ centuries B.C., who have had a significant impact on the further development of management thought even on the contemporary growing state power of this country being the second largest economy in the world. Their treaties include statements containing a communicative element, which reflects the principles of relationships between government and the population: governors, officials, and subjects. This attention to such issues was dictated by the growing output of labor, land reforms, and a struggle for developing a united centralized state. This points to the first insights into a link between information and communications, and also the use of information for political purposes and goals, i.e. to oppose other doctrines, enemy intentions, and in a number of other administrative functions.

Early politicization and certain socialization of ancient Chinese philosophic thought were caused by a fundamental transformation of the country's social and state structure, increasing interest of the government elite and all the administrative communities in upgrading, significantly improving the state administration system. In the process of being established, the first schools of philosophy tended to be encompassed by the state and their prominent representatives were engaged in the administration activities with

${ }^{10}$ Rubin V. A. (1969) Chelovek v drevnekitajskoj my'sli [Man in ancient Chinese though]. Peoples of Asia and Africa. No. 6. P. 65. 
philosophers being invited to public offices and a philosophical administrative academy being set up in the Chi Kingdom. These processes were accompanied by heated and live discussions, bitter debates between representatives of different schools. There was a wide discourse on the formation of the state administration principles and methods, relationships between the governor, officials, and the people, i.e. communications between them in contemporary terms.

Confucius or Kong Fuzi (551-479 B.C.) was the most important and influential figure among ancient Chinese thinkers, who was one of the first philosophers to propose his views and principles on these issues ${ }^{11}$. His doctrine described by his disciples in the Discussions and Judgments treaty shows clear requirements for methods of administering countries and peoples based on generalized and improved moral and ethical rules followed in large Chinese families and society. This doctrine was later called Confucianism. Confucius's historical role, importance, and authorship was recognized in the $2^{\text {nd }}$ century B.C. Obligatory examinations on the basics of classical Confucianism to be passed by Chinese officials were introduced in 125 B.C. and remained unchanged for over two thousand years. An official had to pass them successfully to be admitted to the imperial service. This tradition is still respected and improved for public office. Under the first governor of the Khan dynasty (202 B.C. - 220 A.D.), Confucianism was declared the official state ideological doctrine ${ }^{12}$. Confucianism continues having a serious ideological importance for the formation of contemporary power of the People's Republic of China. The philosophical field called Confucianism began to develop only in the $11^{\text {th }}$ century A.D. although Confucius created his special ethical and political system of views and concepts of state administration one and a half thousand years before that. This is quite normal from a historical standpoint. $\mathrm{He}$ based state administration on ethical rules and moral principles to be followed by governors and officials of all the state hierarchy levels. The moral example of a statesman's conduct is the main ethical principle underlying the trust placed by the population in government and one of the key administration principles.

The art of communication (in the modern sense) plays a well-deserved place in its "proper state administration" system. Confucius believed that the conduct of subjects can be influenced only through direct communications,

11 Ostapets Yu. (2011) Konfuczi’j. Poli'tichna encziklopedi'ya [Confucius. Political Encyclopedia] / edited by Yu. Levenets and others, Kyiv. Parliamentary Publishing House, p. 363.

${ }^{12}$ Macklin I. and Macmillan A. (2005) Korotkij oksfords 'kij poli'tichnij slovnik [Brief Oxford political dictionary] / edited by, translated from English by V. Sydorov and others, Kyiv, Osnovy, p. 341. 
helping maintain stability and honesty in society. He showed a natural example to draw an analogy of this communications model of influence: wind - grass. The power of wind (administration system - administration body) has a direct impact on grass (the population - administered subject) by sagging and directing it. As a result, he recognizes only the unilateral direction of communications in the "government - subjects" system (Confucius, 2006).

Confucius recommended maintaining a reliable distance between the populace and government at all times and preached that government should be internally closed. He believed that communicativeness should be most reasonably implemented through rituals. According to Confucius, communications consisted of three components of "a proper way" - "Tao". These three components included the "zhen" hieroglyph meaning humanity and two symbols: "man" and "two". In this way, the hieroglyph expressed relationships between people. The second component was the "reciprocity" concept - "shu". The third key component was the "golden mean" concept "chzhun-yun", achievement of which was the most complicated and difficult process to ensure an understanding of reciprocity through the stable communicative interaction between people.

Various doctrines that emerged in Ancient China before Christ also included doctrines covering communications to some extent, but in a less deep and consistent manner than Confucianism. One of them, called "moism", was founded by Mozi in the $5^{\text {th }}$ century B.C. Shan Yan was a leader of another field in the $4^{\text {th }}$ century B.C. called "legism". In the late $3^{\text {rd }}$ century B.C., criteria for approaches to an understanding of the "communications balance" between different classes of the population arose in the context of interpretations of these fields. A theoretical attempt to find this balance of interests through communications components was good and promising, although it had no chance of being recognized back then. But the motto saying that "the rich will share with the poor" was later derived from this doctrine and became unfeasible. This unrealistic postulate has existed for over two thousand years. It still suits some present-day politicians from time to time, in which case this motto appears in a new form. Besides, there are attempts not just to proclaim it again, but to implement it in social practice without being aware of this thesis origin, full context, and meaning. Millennium-long experience in failing to implement and permanently misstating this thesis is far from embarrassing importunate demagogues - its apologists as they confuse even nowadays the mind of contemporaries from time to time with outdated false theories refuted by historical practice.

These techniques tested for thousands of years are still successfully used by political strategists in social communications when the mythologeme of 
one system, formation needs to be replaced with another one (the positive one with the negative one and vice versa) and continue to have a limited communicative effect. This method became an infallible tool of an information war particularly in case of discrediting or, otherwise, exalting the current or past personalities not at the best time of social and economic transformations.

A doctrine opposing Confucianism and Moism appeared later and became one of the main teachings in Ancient China; it was stated in the same-name treaty called Zhuangzi in the form of polemic parables calling for return to natural sources of being, i.e. a simple and plain life embodied in dao. Daoism emerged in the early $4^{\text {th }}$ century B.C. and became one of the religious movements in the $2^{\text {nd }}$ century B.C. when Lao Tzu's Dao De Zin treaty was published (Yan Khin-shun, 1950).

Later in their works the prominent representatives of China's schools of philosophy departed from strictly patriarchal, family-based approaches to the society's political life, administration, and communications in its various communities and structures. Search for the optimal forms of organizing society by using the quality of the governors and the governed became the main idea in the teachings of Chinese thinkers. Only a balance and optimal relation of the skills of administrators and society in combination with properly developed communications ensure the order and stability in the state.

At present, not only scientific discussions, dedicated to social administration and the role of communications between government and the population, are held in South-East Asia, but there is a real struggle of the conceptual principles of the development of the national state administration bodies. At the same time, this struggle extended to international systems and transnational corporations, which are playing an increasingly important role in the system of inter-state relations. Stability or instability of the present and future new world order now depends on the results or consequences of this struggle of different management and communications concepts. A two-year trade war between the USA and China, the world's two most powerful economies (accounting for one third to $40 \%$ of the global GDP), is a bright example of this struggle. At the very beginning of 2020, the trade conflict finally returned to the first phase of official agreements: conclusion of the first compromise agreements, which may have a positive impact on the total global situation. However, a no less fierce conflict and, at the same time, interaction of these states in other areas of the global activities due to discrepancies of fundamental worldview concepts will continue for a long time.

An updated oriental philosophical and administration teaching called "Dao" is one of such concepts; it encompasses the fundamental principles of Confucianism, other Chinese doctrines mentioned above and contemporary 
management concepts. Dao actually constitutes a worldview basis of a synergetic approach to management of sophisticated multidimensional nonlinear systems of contemporary society, synthetized based on the experience and many management ideas proposed by South-East Asian thinkers of the past. For instance, one of the postulates of Daoism still used shows that "an object receives life by being implanted in an empty flow of rearrangements" $" 13$. In other words, the world around us is a dynamic process of interactions and changes. This is emphasized in the Book of Changes stating that the laws of nature are not external forces with respect to objects; they make movements proper for objects harmonious ${ }^{14}$. Therefore, both management and communications represent the predicted patterns of the concept of spontaneity of all in the philosophy of the public system, common sense, and practical knowledge.

In the modern sense, this is an organization concept of society administration. The Chinese society administration and the state functioning methodology are deeply based on the philosophical principle of an organic link between man and nature. This principle along with the Chinese devotion to their traditional mental perception of statehood in any forms and in conjunction with all the natural processes explains the high stability of the Chinese civilization and also clarifies the prompt and impressive success of China on the international arena.

\section{CONCLUSIONS}

The studies and analysis of the first historical ideas and theoretical concepts of the role, place, and importance of communications in the state administration systems proposed by the pleiad of the prominent thinkers of the past permit to rethink the sources of conceptual principles of communication studies determined in the $20^{\text {th }}$ century and approach the objective evaluation of the prospective role of the communication component of the humankind civilization development in the $21^{\text {st }}$ century.

Although the first brave intuitive speculations about the role of relationships between government and the population were proposed back in the $6^{\text {th }}-3^{\text {rd }}$ centuries B.C., and theoretical views on the processes and role of communications in the state administration of various periods are presented in the works of the prominent political thinkers of that time, a scientific understanding of the importance of communications for the development of

${ }^{13}$ Maliavin V.V. (2000) Sumerki Dao : Kul'tura Kitaya na poroge Novogo vremeni [Dao darkness: Chinese culture at the threshold of the New Time] Moscow. Design, p. 44.

14 Kapra F. (1994) Dao Physici [Dao of Physics] / translated from English by P. L. Grokhovsky, S. Petersburg: ORIS, p. 198. 
the earth civilization came only when mass communications technology and means became available and began to be widely used in the second quarter of the $20^{\text {th }}$ century.

By the start of the $2020^{\text {th }}$, the humankind had approached the need of an objective scientific understanding of the dominating role of all the types of communications in the general theory of noospheric management of social and economic processes on the Earth in general. What ancient philosophers made intuitive statements of and what M. Weber tried to draw the society's attention to (at the end of World War I), then V. Vernadsky (at the end of World War II), and several other researchers not long ago, has now become an imperative and practical requirement. But this process of rethinking the need for and urgency of a new comprehensive management and communications paradigm is far from being completed and must go through a difficult and heated discourse.

Organistic management concepts of the East relied on the ideas of philosophers of Ancient China. Concepts of antique thinkers were quite similar to them, but practices of management technology fundamentally differed in the historical development process. They were incorporated in the different civilization systems of the West and the East. Only recently have eastern management theories and practices found feedback in the contemporary European management science. This process is even more difficult in the American management science, but it is becoming more and more acceptable, important, and even influential. The synergetic effect will take place only when these management movements departed in the past historical development get synthesized into a comprehensive concept of managing the new world order based on updated organistic and noosphere theories.

\section{SUMMARY}

The Chapter looks at the role and importance of communications in the systems of administration of state bodies in Ancient Greece, Rome, and China as reflected in the works of the prominent thinkers of that time according to their understanding of the essence of this phenomenon in the relevant historical period. It shows that the history of philosophical and political thought knows some well-grounded concepts of relationships between government and the population. Worldviews of antique and ancient Chinese thinkers are rethought in a detailed and systemic manner from the perspective of the contemporary theory of management and communications relationships for the $21^{\text {st }}$ century. It considers methods of practical impacts on the enemy's communications, on the population of their own and neighboring countries, the enemy's structures and other facilities arising in the statehood 
establishment period, including in parallel in the territories of South-East Europe and Asia in the $6^{\text {th }}-3^{\text {rd }}$ centuries B.C.

We analyzed the impact of Plato's and Aristotle's management and communications ideas on the subsequent works of Plutarch, Caesar, Cicero, and other antique authors as well as the influence of their ideas on the concepts of contemporary researchers. It is shown that Aristotle's communications formula has had a dominant and exclusive impact on the understanding of this phenomenon for over two thousand years. The Chapter presents the key principles of Confucius's doctrine bearing on the fundamental issues of management, hierarchy of government and their internal communications, social and ethical rules of relationships between officials and the people, communications between government services and society.

\section{REFERENCES}

1. Aristotle (2000) Polityka [Polity] / translated from Ancient Greek and foreword by O. Kysliuk, Kyiv, Osnovy. [in Ukrainian]

2. Aristotle. Retorica [Rhetoric] (2000) Poetry / translated from Ancient Greek by O. Tsybenko. Moscow, Labirint. [in Russian]

3. Kapra F. (1994) Dao Physici [Dao of Physics] / translated from English by P. L. Grokhovsky, S. Petersburg: ORIS. [in Russian]

4. Kislov D. (2019) Establishment of scientific research in communication studies in the 1920-1930s. History of science and technology. Vol. 9, issue 1 (14). P. 99-108. DOI: https://doi.org/10.32703/2415-74222019-9-1(14)-99-108 [in Ukrainian]

5. Macklin I. and Macmillan A. (2005) Korotkij oksfords'kij poli'tichnij slovnik [Brief Oxford political dictionary] / edited by, translated from English by V. Sydorov and others, Kyiv, Osnovy. [in Ukrainian]

6. Maliavin V.V. (2000) Sumerki Dao : Kul'tura Kitaya na poroge Novogo vremeni [Dao darkness: Chinese culture at the threshold of the New Time] Moscow. Design. [in Russian]

7. Mommsen T. (1997) Istoriya Rima : v 4 tomah [History of Rome: in 4 volumes]. Rostov on Don. Fenix. [in Russian]

8. Ostapets Yu. (2011) Konfuczi'j. Poli'tichna encziklopedi'ya [Confucius. Political Encyclopedia] / edited by Yu. Levenets and others, Kyiv. Parliamentary Publishing House, p. 363. [in Ukrainian]

9. Plato. (1999) Zakony [Laws] / translated from Ancient Greek by A. Losev, V. Asmus, A. Godi. Moscow. Mysl, p. 618 [in Russian]

10. Pocheptsov G.G. (2002) Psikhologicheskie vojny [Psychological wars]. Moscow. Refl-book, Kyiv. Vakler. [in Ukrainian; in Russian] 
11. Rubin V.A. (1969) Chelovek v drevnekitajskoj my'sli [Man in ancient Chinese though]. Peoples of Asia and Africa. No. 6. p. 74-85 [in USSR]

12. Tacitus C. (1969) Istoriya. Istoriki Rima [History. History of Rome]. Moscow. Nauka. [in USSR]

\section{Information about the author:}

Denis Kislov,

Institute of Law and Public Relations, Open International University of Human Development "Ukraine"

23, Lvivska str., Kyiv, 03115, Ukraine

ORCID: https://orcid.org/0000-0002-9112-9832 